\title{
ESTIMATION OF UNDERWATER OPTICAL COMMUNICATION LINK OPERATING DISTANCE
}

DOI: $10.36724 / 2072-8735-2020-\mid 4-3-54-60$

\author{
Aleksej V. Shherbakov, \\ Moscow Technical University of Communications and Informatics, \\ Moscow, Russia
}

Gennadij D. Petruhin, Moscow Technical University of Communications and Informatics, Moscow, Russia

Natalija E. Miroshnikova,

Moscow Technical University of Communications and Informatics, Moscow, Russia, n.e.miroshnikova@mtuci.ru

Pavel A. Titovets, Moscow Technical University of Communications and Informatics, Moscow, Russia, paveltitovec@mail.ru

\begin{abstract}
Keywords: underwater optic communication links, underwater wireless communication systems, operating distance, optical communication, communication range, vertical and horizontal tracks
\end{abstract}

\begin{abstract}
currently, the active investigation of hydrosphere is carried out with the use of various stationary and mobile underwater vehicles. In many situations, wireless communication is required between these devices. Today this problem is solved with the use of acoustic and radio waves, as a rule, the low frequency range. The main disadvantages of both acoustic and radio lines are: low speed of information transmission and high power consumption. The use of underwater (hydrosphere) communication lines as carriers of electromagnetic oscillations of the optical range can significantly increase the transmission speed, reduce power consumption while reducing the weight and size of the receiving and transmitting modules. The analysis of the literature, which deals with theoretical and technical problems and problems arising in the design of underwater optical communication lines (UWOL), showed that the estimates of the potential range and transmission speed differ significantly from one author to another. Some sources do not clearly define the conditions for measurements and computational experiments. In this regard, the question arises about the construction of a universal methodology for assessing the potential characteristics of UWOL. The purpose of this work is to build a methodology for assessing the potential characteristics of the UWOL, which takes into account the main factors affecting the transmission distance of information in the UWOL only from the energy point of view. Dispersion properties of the hydrosphere affecting the transfer rate are not taken into account in the model. Novelty: the novelty of the presented technique is the possibility of assessing the potential range of communication for both horizontal and vertical routes, and taking into account the influence of the characteristics of the element base (lasers, photodetectors) on the parameters of the UWOL. The technique also takes into account the possibility of changing the vertical profile of the refractive indices of the aquatic environment and the concentration of chlorophyll, which allows to estimate the potential range of GLS for different geographical points of the ocean.
\end{abstract}

Information about authors:

Aleksej V. Shherbakov, Ph.D. doctoral candidate, Research Assistant, Moscow Technical University of communication and Informatics, Moscow, Russia Gennadij D. Petruhin, holder of an Advanced Doctorate in Engineering Sciences. Leading Recearch Officer, Moscow Technical University of communication and Informatics, Moscow, Russia

Natalija E. Miroshnikova, Ph.D. of Engineering Sciences. Research Officer, Moscow Technical University of communication and Informatics,

Moscow, Russia

Pavel A. Titovets, leading engineer of the research department, Moscow Technical University of communication and Informatics, Moscow, Russia

Для цитирования:

Петрухин Г.Д., Мирошникова Н.Е., Щербаков А.В., Титовеи П.А. Оценка протяженности гидросферной оптической линии связи // T-Comm: Телекоммуникации и транспорт. 2020. Том I4. №3. С. 54-60.

For citation:

Shherbakov A.V., Petruhin G.D., Miroshnikova N.E., Titovets P.A. (2020) Estimation of underwater optical communication link operating distance. T-Comm, vol. 14, no.3, pp. 54-60. (in Russian) 


\section{Introduction}

Currently, in underwater wireless communication systems (UWCS) acoustic waves are most commonly used. One of the drawbacks of acoustic UWCS is their low bandwidth (data transfer rate up to tens of kbit/s for distances of the order of kilometers, and to hundred kbit/s transmission at several meters distance). Use radiofrequency electromagnetic waves in UWCS does not fundamentally solve the problems of range and transmission speed.

Obviously, the bandwidth of the communication channel could be definitely increased with the use of optical frequency band. However, a very high level of attenuation of optical waves did not allow developers to treat them for widespread use in UWCS. The situation has changed after detection that in the wavelength range of $0.4-0.55$ microns, wherein the attenuation was quite acceptable for the realization of operable optical UWCS [1, 2]. There also have been developed semiconductor emitters (LEDs, lasers) with high power (to tens of watts) enough and with acceptable performance.

In 1994, an article was published [3] which demonstrated the possibility of underwater wireless optical link (UWOL) organization with suitable properties for practical use. Since then there has been a sharp increase in publications on the subject.

In the article [4] there is an overview of the existing optical UWCS and UWOL modeling methods.

\section{Proposed estimation methodology}

Analysis of the available literature [5-8] showed that the potential operating distance and transmission rate obtained by different authors vary considerably. Some sources are not clearly define the conditions of measurement and computational experiments.

In this regard, there is a question of constructing a universal workable methodology to assess the potential performance of UWOL. In this article, the authors attempt to estimate the operating distance of UWOL using information about the characteristics and parameters of the hydrosphere.

The flowchart of proposed estimation methodology is shown in Figure 1.

The calculation is carried out for both horizontal and vertical links. When calculating the vertical link, the refractive index profile and the chlorophyll concentration is considered.

Source can be specified as a laser or LED.

Absorption, scattering, salinity, temperature and water pressure are taken into account when evaluating the received power.

The general attenuation $c(\lambda)$ can be obtained as the sum of the absorption coefficients $[a(\lambda)]$ and scattering $[b(\lambda)][4]$ :

$$
c(\lambda)=a(\lambda)+b(\lambda)
$$

Summary of the absorption coefficient of the propagation path can be found as the sum of the actual absorption coefficient of sea water and the absorption coefficient of organic substances [9]:

$$
a(\lambda)=a_{w}(\lambda)+a_{f} c_{f} \exp \left(-k_{f} \lambda\right)+a_{h} c_{h} \exp \left(-k_{h} \lambda\right)+a_{c}(\mathrm{cc})^{0.602} .
$$

where $a_{w}(\lambda)$ - absorption coefficient of pure water, $a_{f}-$ specific absorption coefficient of fulvic acids, $a_{h}$ - absorption coefficient of humic acids, $a_{c}$ - absorption coefficient of chlorophyll, $c_{f}$ - the concentration of humic acids, $c_{h}$ - the concentration of chlorophyll $k_{f}$ - exponential coefficient of fulvic acids $k_{h}$ - exponential coefficient of humic acids.

Set up direction (horizontal or vertical), the
refractive index profile.
Set up initial distance between transmitter and
receiver $=1 \mathrm{~m}$
receiver $=1 \mathrm{~m}$

Set up parameters of photodetector and transmitter (source type, modulation type, aperture of photodetector, field of view (FOV) of the photodetector)

\section{7}

Determination of the required signal / noise ratio for a given error probability for the selected modulation type

\section{7}

Calculation of link attenuation and received signal power for all chosen distances.

Calculation of signal / noise ratiofor all chosen
distances.
$\begin{aligned} & \text { Build dependency graph of the signal / noise } \\ & \text { ratio vs the distance }\end{aligned}$
Build dependency graph of the signal / noise
ratio vs the distance

Fig. 1. Flowchart of proposed estimation methodology

To account for the influence of the concentration of chlorophyll in damping used in the following numerical coefficients whose values are taken from [10]:

$$
\begin{aligned}
& C f=1.74098 \cdot c c \cdot \exp (0.12327 \cdot c c), \\
& C h=0.19334 c c \cdot \exp (0.12343 c c), \\
& C s=0.0173 \cdot c c \cdot \exp (0.11631 \cdot c c), \\
& C s=0.66284 \cdot c c \cdot \exp (0.03092 \cdot c c), \\
& a_{c}(\lambda)=A(\lambda) c c^{B(\lambda),}
\end{aligned}
$$

Chlorophyll concentration distribution in the photic zone defined [13]:

$$
c c(z)=B_{0}+(S \times z)+\frac{1}{\sigma \sqrt{2 \pi}} \exp \left(-\frac{\left(\mathrm{z}-z_{\max }\right)^{2}}{2 \sigma^{2}}\right),
$$


where $c c(z)$ - chlorophyll concentration on depth $\mathrm{z}, B_{0}$ - background concentration of chlorophyll in the surface layer, $\mathrm{S}$ - chlorophyll concentration gradient in the vertical direction, $\sigma-$ standard deviation of a Gaussian distribution, which determines the maximum chlorophyll layer thickness, and $z_{\max }-$ depth of maximum chlorophyll concentration.

Standard deviation chlorophyll concentration $\sigma$ is given by:

$$
\sigma=\frac{h}{\sqrt{2 \pi}\left(c c_{z \max }-B_{0}-(S \times z)\right.} \text {. }
$$

Optical scattering coefficient can be represented in accordance with the [9] as:

$$
b(\lambda)=b_{w}(\lambda)+b_{s}(\lambda) C s+b_{l}(\lambda) C l,
$$

where $b_{w}$ - dissipation factor in pure water, $b_{s}$ - dissipation factor for small (compared with the wavelength) chlorophyll particles, $b_{l}$ - dissipation factor for large (compared with the wavelength) chlorophyll particles, Cs - concentration of small chlorophyll particles, $\mathrm{Cl}$ - concentration of large chlorophyll particles.

Rayleigh scattering model is used for particles smaller than the wavelength, and the Mi model - for particles with size larger than the wavelength. For Rayleigh scattering model dissipation factor in clean sea water $b_{w}(\lambda)$ It is defined as:

$$
b_{w}(\lambda)=0.005826\left(\frac{400}{\lambda}\right)^{4.322}
$$

For isotropic scattering, the probabilities of direct and inverse scattering are equal, so the volume scattering function empirically expressed as [11]:

$$
\beta_{w}(\lambda)=0.06225\left(1+0.835 \cos ^{2} \theta\right)
$$

The dissipation factor for large particles:

$$
b_{l}(\lambda)=0.005826\left(\frac{400}{\lambda}\right)^{1.17}
$$

The dissipation factor for small particles:

$$
b_{s}(\lambda)=0.341074\left(\frac{400}{\lambda}\right)^{0.3} \text {. }
$$

For horizontal line-of sight link, the power of the received signal $\mathrm{P}_{\mathrm{R}_{-} \text {LOS }}$, in accordance with the proposed method, is given by [14]:

$$
\mathrm{P}_{\mathrm{R}_{-} \text {LOS }}=\mathrm{P}_{\mathrm{T}} \eta_{\mathrm{T}} \eta_{\mathrm{R}} \mathrm{L}_{\mathrm{P}}\left(\lambda, \frac{\mathrm{d}}{\cos (\theta)}\right) \frac{\mathrm{A}_{\mathrm{R}} \cos (\theta)}{2 \pi \mathrm{d}^{2}\left(1-\cos \left(\theta_{\mathrm{d}}\right)\right)},
$$

where $\mathrm{P}_{\mathrm{T}}$-the average optical power of the transmitter, $\eta_{T}$ and $\eta_{R}$ - optical efficiency of transmitter and receiver, respectively, $\mathrm{d}$ - Euclidean distance between the transmitter and receiver plane, $\theta$ - angle between the perpendicular to the plane of the receiver and the transmitter-receiver path, $A_{R}$ - receiver aperture area and $\theta_{d}$ - the divergence angle of the laser beam.
For horizontal line-of sight link, the power of the received signal $P_{R_{-} \text {LOS_v }}$ is calculated according to [15]:

$$
\begin{aligned}
& \mathrm{P}_{\mathrm{R}_{-} \text {LOS_v }_{-}}=\mathrm{P}_{\mathrm{T}} \eta_{\mathrm{T}} \eta_{\mathrm{R}} \mathrm{L}_{\mathrm{P}}(\theta) \mathrm{A}_{\mathrm{R}} \cos (\theta) \\
& \mathrm{L}_{\mathrm{P}}(\theta)= \\
& =\left\{\begin{array}{c}
\frac{1}{A_{L}} \exp \left\{-\sum_{i=1}^{N} \frac{d_{i} c_{i}(\lambda)}{\cos \left(\theta_{i}\right)}\right\} \prod_{i=1}^{N} T_{i, i+1}, \phi_{m, n} \leq \theta<\min \theta_{c}\left(w_{w}, \quad\right) . \\
0, \quad \text { for } \theta_{\text {min }} \leq \theta<\theta_{\max }
\end{array}\right.
\end{aligned}
$$

where $A_{L}=2 \pi R\left(H_{\text {max }}-H_{\text {min }}\right) . \theta_{c, w w}=\sin ^{-1}\left(\frac{n_{w_{i+1}}}{n_{w_{i}}}\right)$.

Signal to noise ratio is calculated by the following equation [16]:

$$
\begin{aligned}
& S N R=\frac{P_{r x}^{2} R_{L}\left(\frac{q Q E}{h v}\right)^{2}}{2 q G^{2} R_{L} B\left(i_{d}+\frac{q Q E}{h v}\left(P_{s o l}+P_{r x}\right) 4\right)+k T B} . \\
& \mathrm{P}_{\mathrm{BG} \_ \text {solar }}=\mathrm{A}_{\mathrm{r}} \times \text { FovFac } \times \Delta \lambda \mathrm{T}_{\mathrm{F}} \mathrm{L}_{\text {sol }} .
\end{aligned}
$$

Where $\mathrm{A}_{\mathrm{r}}$ - aperture, FovFac $=\pi\left(\mathrm{FOV}^{2}\right), \mathrm{FOV}-$ field of view, $\Delta \lambda$ is the width of the optical band pass filter, and $T_{F}$ represents the bandwidth of the optical filter.

Solar luminosity $\mathrm{L}_{\mathrm{sol}}\left(\mathrm{W} / \mathrm{m}^{2}\right)$ defined as:

$$
\mathrm{L}_{\mathrm{sol}}=\frac{\mathrm{ERL}_{\mathrm{fac}} \exp \left(-\mathrm{KD}_{\mathrm{w}}\right)}{\pi}
$$

where $\mathrm{E}$ is the incident light power $\left(\mathrm{W} / \mathrm{m}^{2}\right), \mathrm{R}-$ the coefficient of reflection of the incident radiation, $\mathrm{L}_{\text {fac }}-$ parameter describing the dependence of the emission intensity from the direction, $\mathrm{K}$ - diffuse attenuation coefficient, and $\mathrm{D}_{\mathrm{w}}-$ depth.

\section{Results of estimation}

When calculating by the proposed method, the following values of the receiver aperture diameter is considered: $8 \mathrm{~mm}, 25$ $\mathrm{mm}, 51 \mathrm{~mm}, 76 \mathrm{~mm}$ and $101 \mathrm{~mm}$. The selection of these values associated with their use in real hardware.

The parameters in the calculation of the signal / noise ratio for some type of photodetectors shown in table 1.

Three types of photodetectors is considered: avalanche photodetectors (APD) based on germanium and silicon and silicon PIN photodiodes.

Table 1

Parameters for calculating the signal/noise ratio

\begin{tabular}{|l|c|c|c|}
\hline & Si APD & Ge APD & PIN Si \\
\hline gain G & 150 & 50 & 1 \\
\hline The noise factor F & 0.5 & 0.95 & - \\
\hline Dark current, id & $15 \mathrm{nA}$ & 700 & $10 \mathrm{nA}$ \\
\hline The quantum efficiency QE & 0.77 & 0.75 & 0.85 \\
\hline
\end{tabular}

In table 2 the numerical values of parameters used to calculate the vertical profile of the chlorophyll concentration are shown [17]. 


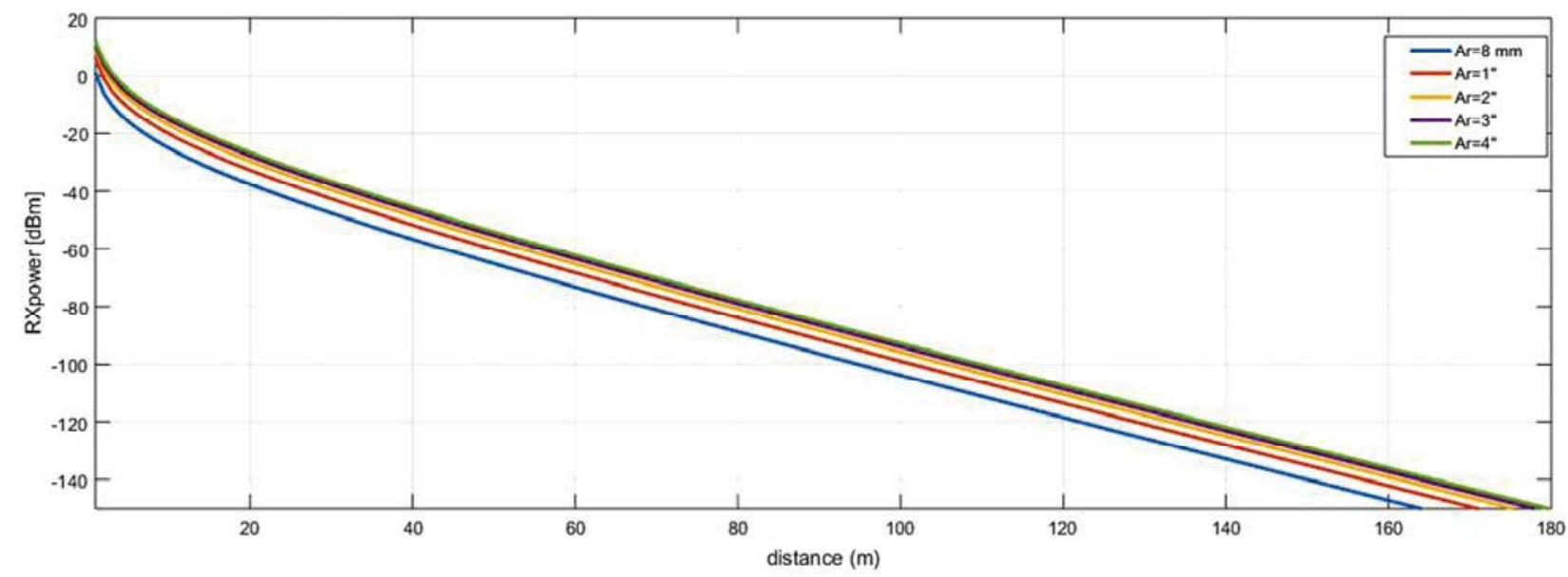

Fig. 2. The dependence of the received power $(\mathrm{dBm})$ from the distance $(\mathrm{m})$ for different values of the photo detector aperture $A_{R}$

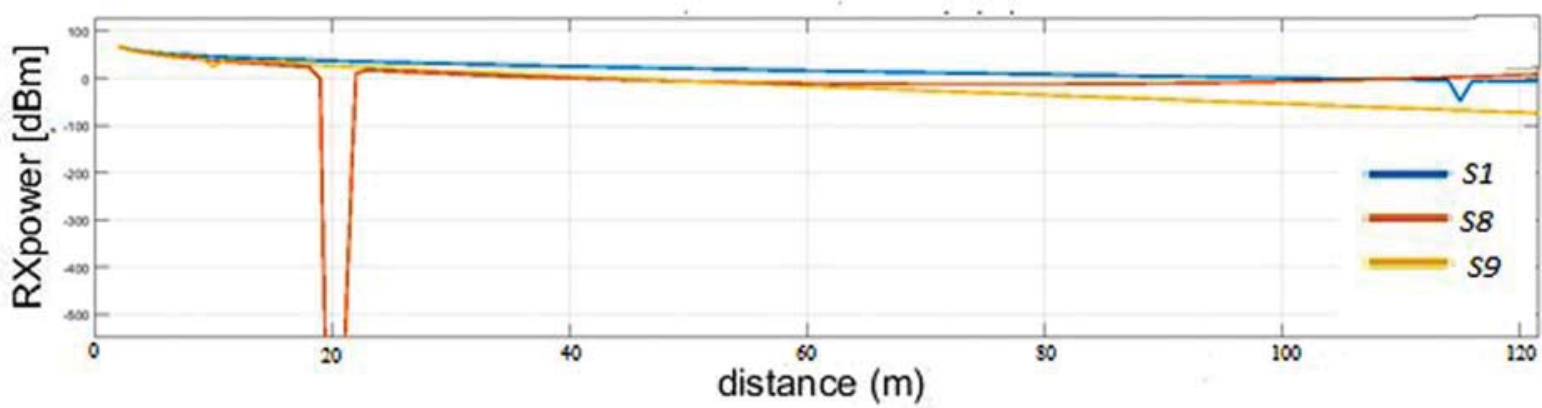

Fig. 3. Depending on the received power $(\mathrm{dBm})$ at a vertical distance from distributing three different distribution profiles of chlorophyll (S1, S8 and S9)

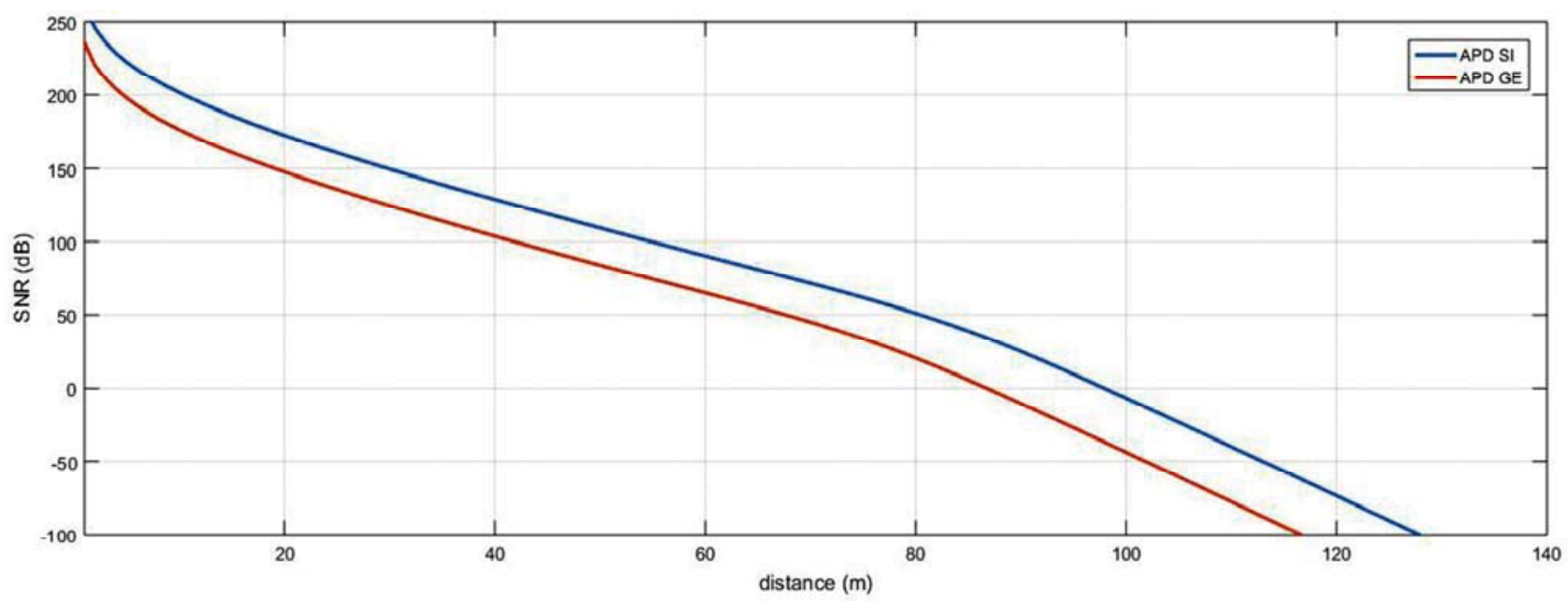

Fig. 4. Dependence of signal / noise ratio from the distance in the horizontal link.



Fig. 5. Dependence of signal / noise ratio of the distance in the transmission in pure water ( $\mathrm{S} 1$ chlorophyll distribution profile) 
Numerical values of parameters used to calculate the vertical profile of the chlorophyll concentration

\begin{tabular}{|l|l|l|l|l|l|l|l|}
\hline Profile & $\begin{array}{c}|c| \\
\text { Surface } \\
\text { chlorophyll } \\
\text { concentration } \\
(\mathrm{Mg} / \mathrm{m} 3)\end{array}$ & $\begin{array}{c}\mathrm{B} 0 \\
(\mathrm{Mg} / \mathrm{m} 3)\end{array}$ & $\begin{array}{c}\mathrm{S} \\
(\mathrm{X} 10-3) \\
(\mathrm{mg} / \mathrm{m} 2)\end{array}$ & $\begin{array}{c}\mathrm{h} \\
(\mathrm{Mg})\end{array}$ & $\begin{array}{c}\text { zmax } \\
(\mathrm{M})\end{array}$ & $\begin{array}{c}\text { Cchl } \\
(\mathrm{Zmax}) \\
(\mathrm{Mg} / \mathrm{m} 3)\end{array}$ & $\begin{array}{c}\mathrm{Z} \infty \\
(\mathrm{M})\end{array}$ \\
\hline $\mathrm{S} 1$ & $<0.04$ & 0.0429 & $-0,103$ & 11.87 & 115.4 & 0.708 & 415.5 \\
\hline $\mathrm{S} 2$ & $0.04-0.08$ & 0.0805 & $-0,260$ & 13.89 & 92.01 & 1.055 & 309.6 \\
\hline $\mathrm{S} 3$ & $0.08-0.12$ & 0.0792 & $-0,280$ & 19.08 & 82.36 & 1.485 & 282.2 \\
\hline $\mathrm{S} 4$ & $0.12-0.2$ & 0.143 & $-0,539$ & 15.95 & 65.28 & 1.326 & 264.2 \\
\hline S5 & $0.2-0.3$ & 0.207 & -1.03 & 15.35 & 46.61 & 1.557 & 200.7 \\
\hline $\mathrm{S} 6$ & $0.3-0.4$ & 0.160 & $-0,705$ & 24.72 & 33.03 & 3.323 & 226.8 \\
\hline $\mathrm{S} 7$ & $0.4-0.8$ & 0.329 & -1.94 & 25.21 & 24.59 & 3,816 & 169.1 \\
\hline S8 & $0.8-2.2$ & 1.01 & -9.03 & 20.31 & 20.38 & 4,556 & 111.5 \\
\hline S9 & $2.2-4$ & 0.555 & 0 & 130.6 & 9.87 & 136.5 & - \\
\hline
\end{tabular}

On the Figure 2 the dependence graph of received signal power vs the distance in the case of the horizontal link is shown. Dependencies are presented for various receiver aperture values. Transmitter power $1 \mathrm{Wt}$.

On Figure 3 represented dependency graph of the received power vs the distance in the case of vertical link. Dependencies are presented for three different distribution profiles of chlorophyll. Transmitter power 1 watt.

On the Figure 3 a great decrease in signal power at the depth of the maximum concentration of chlorophyll well shown.

On the Figure 4 dependency graphs of the signal / noise ratio vs the distance in the case of the horizontal link is shown. The figure shows the dependence of different types of detectors. Transmitter power 1 watt. The aperture of the receiver $101 \mathrm{~mm}$.

On the Figure 5 Dependence of signal / noise ratio from the distance in the vertical link is shown. Profile S1 of chlorophyll concentration is used for different types of detectors. Transmitter power $1 \mathrm{Wt}$. The aperture of the receiver $101 \mathrm{~mm}$.

The results of operational distance calculation for the horizontal and vertical links for maximum transmitter power (50 $\mathrm{Wt}$ ) are summarized in table 3 and table 4 respectively.

Required power is calculated based on the average error probability 10-3. Considered case is intensity modulation with direct detection, NRZ encoding. The required value of the signal / noise ratio to achieve the desired probability of error calculated in accordance with expression [18]

$$
B E R_{O O K-N R Z}=\frac{1}{2} \operatorname{erfc}\left(\frac{1}{2 \sqrt{2}} \sqrt{S N R}\right)
$$

Where $B E R_{O O K-N R Z}$ - error probabilities for the case of modulation of intensity, encoding NRZ, SNR - signal to noise ratio. For a given desired probability of error of 10-3 signal to noise ratio is $9 \mathrm{~dB}$.

For calculation the wavelength equal to $548 \mathrm{~nm}$ and a receiver aperture diameter of $20 \mathrm{~cm}$ is chosen.
Operational distance $(\mathrm{m})$ for the maximum transmitter power $(50 \mathrm{~W})$ (horizontal link)

\begin{tabular}{|c|c|c|c|c|c|c|}
\hline & \multicolumn{6}{|c|}{ Horizontal spread } \\
\hline $\begin{array}{l}\text { Radiation } \\
\text { Source: }\end{array}$ & \multicolumn{3}{|c|}{ LED } & \multicolumn{3}{|c|}{ Laser } \\
\hline $\begin{array}{l}\text { type of } \\
\text { detector } \\
\text { The type of } \\
\text { water } \\
\end{array}$ & APD SI & APD GE & PIN Si & APD SI & APD GE & PIN Si \\
\hline Pure water & 125 & 120 & 40 & 180 & 170 & 80 \\
\hline $\begin{array}{l}\text { Water coastal } \\
\text { zone }\end{array}$ & 45 & 40 & 20 & 65 & 55 & 25 \\
\hline $\begin{array}{l}\text { Water port } \\
\text { area }\end{array}$ & 50 & 20 & 7 & 25 & 27 & 10 \\
\hline
\end{tabular}

Table 4

Operational distance $(\mathrm{m})$ for the maximum transmitter power $(50 \mathrm{~W})$ (vertical link, receiver module located on the water/air boundary)

\begin{tabular}{|l|c|c|c|c|c|c|}
\hline & \multicolumn{5}{|c|}{ Lertical spread } \\
\hline Radiation Source: & \multicolumn{3}{|c|}{ LED } & \multicolumn{3}{|c|}{ Laser } \\
\hline $\begin{array}{l}\text { type of detector } \\
\text { The type of water }\end{array}$ & APD SI & APD GE & PIN Si & APD SI & APD GE & PIN Si \\
\hline $\begin{array}{l}\text { vertical } \\
\text { distribution profile } \\
\text { chlorophyll type 1 } \\
\text { (pure water) }\end{array}$ & 67 & 65 & 23 & 116 & 116 & 88 \\
\hline $\begin{array}{l}\text { vertical } \\
\text { distribution profile } \\
\text { chlorophyll 8 type } \\
\text { (water coastal } \\
\text { zones) }\end{array}$ & 20 & 20 & 11 & 21 & 21 & 20 \\
\hline $\begin{array}{l}\text { vertical } \\
\text { distribution profile } \\
\text { chlorophyll 9 type } \\
\text { (water port area) }\end{array}$ & 40 & 40 & 28 & 92 & 91 & 58 \\
\hline
\end{tabular}

\section{Conclusions}

The article presents the results of operational distance calculation of UWOL for vertical and horizontal line of sight links, using different transmitting and receiving devices. The obtained results permit the conclusion that underwater wireless optical communication system may provide communication with a communication range of about $100 \mathrm{~m}$, with little power consumption and size suitable transceiver modules.

UWOL possible transmission speed, the feasibility of using in the transmitting module of the phase and polarization manipulations (and hence heterodyne or super heterodyne reception methods), performance features of UWOL when transceiver modules operate at depths free from phytoplankton and chlorophyll requires separate studies. For reliable estimates of UWOL parameters (operational distance and possible transmission rate) numerical values of hydrosphere parameters in different geographical zones in which it will be used is required. 


\section{References}

1. Apel J.R. Principles of Ocean Physics (International Geophysics Series), London, UK: Academic Press, 1987, vol. 38, pp. 509-584.

2. Costello M.J., Cheung A., De Hauwere N. (2010). Surface area and the seabed area, volume, depth, slope, and topographic variation for the worlds seas, oceans, and countries, Env. Sci. \& Tech. Vol. 44. No. 23, pp. 8821-8828.

3. Spinrad R.W., Carder K. L, Perry M.J., (1994). Ocean Optics, Oxford, UK: Clarendon. $464 \mathrm{p}$.

4. Miroshnikova N.E., Petruchin G.S., Sherbakov A.V., (2019). "Problems of Underwater Optical Links Modeling," 2019 Systems of Signal Synchronization, Generating and Processing in Telecommunications (SYNCHROINFO), Russia, pp. 1-9.doi: 10.1109 / SYNCHROINFO.2019.8813996

5. Petzold T.J. (1972). Volume scattering functions for selected ocean waters. Scripps Inst. Oceanogr., La Jolla, CA, USA, Tech. Rep. SIO 72781972.

6. Kopilevich Y.I., Kononenko M.E., Zadorozhnaya E.I. Zadorozhnaya (2010). The effect of the forward-scattering index on the characteristics of a light beam in sea water, J. Opt. Technol. Vol. 77. No. 10, pp. 598-601.

7. Mobley C.D., Sundman L.K., Boss E. (2002). Phase function effects on oceanic light fields, Applied optics, Vol. 41. No. 6, pp. 1035-1050.

8. Haltrin .I. (2002). eter two-term Henyey_Greenstein phase function for light scattering in seawater, Applied Optics, Vol. 41. No. 6, pp. 1022-1028.

9. Haltrin V.I. (1999). Chlorophyll-based model of seawater optical properties, Applied Optics. Vol. 38. No. 33, pp. 6826-6832.

10. Hulburt E.O. (1945). Optics of distilled and natural water, $J$. Opt. Soc. Amer. Vol. 35. No.. 11, pp. 698.
11. Chancey M.A. (2005). Short range underwater optical communication links: MS thesis. Dept. Elect. Eng. North Carolina State Univ. Raleigh, NC, USA.

12. Bogucki D.J., Domaradzki J.A., Stramski D., Zaneveld J.R. (1998). Comparison of near-forward light scattering on oceanic turbulence and particles, Applied Optics. Vol. 37. No. 21, pp. 4669-4677.

13. Sauzide R. et.al. (2015). Vertical distribution of chlorophyll a concentration and phytoplankton community composition from in situ fluorescence profiles: a first database for the global ocean, Earth System Science Data. Vol. 7. No. 2, pp. 261.

14. Arnon S. (2010). Underwater optical wireless communication network, J. Opt. Eng. Vol. 49. No. 1, pp. 015001-1-015001-6.

15. Jaruwatanadilok S. (2008). Underwater wireless optical communication channel modeling and performance evaluation using vector radiative transfer theory, IEEE J. Sel. Areas Commun. Vol. 26. No. 9, pp. 1620-1627.

16. Li C., Park K.H., Alouini M.S. (2013). On the use of a direct radiative transfer equation solver for path loss calculation in underwater communication systems, J. Opt. Commun. Networks. Vol. 5. No. 1, pp. 1-12.

17. Gabriel C., Khalighi M.-A., Bourennane S. (2015). MonteCarlo-based channel characterization for underwater optical optical wireless channels, IEEE Wireless Commun. Lett. Vol. 4. No. 5, pp. 561-564.

18. Mazin Ali A. Ali (2015) Comparison of Modulation Techniques for Underwater Optical Wireless Communication Employing APD Receivers, Research Journal of Applied Sciences, Engineering and Technology, pp. 561-564. 


\title{
ОЦЕНКА ПРОТЯЖЕННОСТИ ГИДРОСФЕРНОЙ ОПТИЧЕСКОЙ ЛИНИИ СВЯЗИ
}

\author{
Петрухин Геннадий Дмитриевич, Московский технический университет связи и информатики, Москва, Россия \\ Мирошникова Наталия Евгеньевна, Московский технический университет связи и информатики, Москва, Россия \\ Щербаков Алексей Валерьевич, Московский технический университет связи и информатики, Москва, Россия \\ Титовец Павел Александрович, Московский технический университет связи и информатики, Москва, Россия, \\ paveltitovec@mail.ru
}

\section{Аннотация}

В настоящее время ведется активное освоение гидросферы Земли с применением различных стационарных и подвижных подводных аппаратов. Во многих ситуациях между этими аппаратами необходима беспроводная связь. На сегодня эта задача решается с использованием акустических и радиоволн, как правило, низкочастотного диапазона. Основными недостатками и акустических, и радиотехнических линий являются: невысокая скорость передачи информации и большое энергопотребление. Использование в подводных (гидросферных) линиях связи в качестве несущих электромагнитных колебаний оптического диапазона позволяет существенно повысить скорость передачи, снизить энергопотребление при одновременном уменьшении массы и размеров приемно-передающих модулей. Анализ литературы, в которой рассматриваются теоретические и технические проблемы и задачи, возникающие при проектировании гидросферных оптических линий связи (ГОЛС ), показал, что оценки потенциальной дальности и скорости передачи у разных авторов значительно отличаются. В некоторых источниках не совсем четко определены условия проведения измерений и вычислительных экспериментов. В связи с этим встает вопрос о построении универсальной методики для оценки потенциальных характеристик ГОЛС. Целью данной работы является построение методики оценки потенциальных характеристик ГОЛС, в которой учитываются основные факторы, влияющие на дальность передачи информации в ГОЛС только с энергетической точки зрения. Дисперсионные свойства гидросферы, влияющие на скорость передачи в методике не учитываются. Предложенная методика позволяет оценить потенциальную дальность связи как для горизонтальной, так и вертикальной трасс, с учетом характеристик элементной базы (лазеров, фотодетекторов). Учитывается возможность изменения вертикального профиля показателей преломления водной среды и концентрации хлорофилла, что позволяет оценить потенциальную дальность ГОЛС для разных географических точек океана.
\end{abstract}

Ключевые слова: гидросферные оптические линии связи, подводная связь, методика проектирования, дальность связи, вертикальная и горизонтальная трассы.

\section{Литература}

I. Apel J. R. (1987). Principles of Ocean Physics (International Geophysics Series). London, U.K.: Academic Press. Vol. 38, pp. 509-584.

2. Costello M. J., Cheung A., De Hauwere N. (2010). Surface area and the seabed area, volume, depth, slope, and topographic variation for the worlds seas, oceans, and countries. Env. Sci. \& Tech. Vol. 44. No. 23, pp. 882I-8828.

3. Spinrad R.W., Carder K.L, Perry M.J., (1994). Ocean Optics. Oxford, U.K.: Clarendon. 464 p.

4. Miroshnikova N.E., Petruchin G.S., Sherbakov A.V., (2019). "Problems of Underwater Optical Links Modeling," 2019 Systems of Signal Synchronization, Generating and Processing in Telecommunications (SYNCHROINFO), Russia, PP. I-9. doi:10.1 I09/SYNCHROINFO.2019.8813996

5. Petzold T.J. (1972). Volume scattering functions for selected ocean waters. Scripps Inst. Oceanogr., La Jolla, CA, USA, Tech. Rep. SIO 7278.

6. Kopilevich Y.I., Kononenko M.E., Zadorozhnaya E.I. Zadorozhnaya (2010). The effect of the forward-scattering index on the characteristics of a light beam in sea water. J. Opt. Technol. Vol. 77. No. 10, pp. 598-60I.

7. Mobley C. D., Sundman L. K., Boss E. Phase function effects on oceanic light fields// Applied optics. Vol 4I. № 6. 2002. P.1035-1050.

8. Haltrin V.I. (2002). One-parameter two-term Henyey_Greenstein phase function for light scattering in seawater. Applied Optics. Vol. 4I. No. 6, Pp. $1022-1028$.

9. Haltrin V.I. (1999). Chlorophyll-based model of seawater optical properties. Applied Optics. Vol. 38. No. 33, pp. 6826-6832.

10. Hulburt E.O. (1945). Optics of distilled and natural water. J. Opt. Soc. Amer. Vol. 35. No.. II, p. 698.

II. Chancey M.A. (2005). Short range underwater optical communication links: M.S. thesis. Dept. Elect. Eng. North Carolina State Univ. Raleigh: NC, USA.

12. Bogucki D.J., Domaradzki J. A., Stramski D., Zaneveld J.R. (1998). Comparison of near-forward light scattering on oceanic turbulence and particles. Applied Optics. Vol. 37. No. 21, pp. 4669-4677.

13. Sauzide R. et.al. (2015). Vertical distribution of chlorophyll a concentration and phytoplankton community composition from in situ fluorescence profiles: a first database for the global ocean. Earth System Science Data. Vol. 7. No. 2, p. 26I.

14. Arnon S. (2010). Underwater optical wireless communication network. J. Opt. Eng. Vol. 49. No. I, pp. I-I5.

15. Jaruwatanadilok S. (2008). Underwater wireless optical communication channel modeling and performance evaluation using vector radiative transfer theory. IEEE J. Sel. Areas Commun. Vol. 26. No. 9. 2008, pp. I620-I627.

16. Li C., Park K.H., Alouini M.S. (2013). On the use of a direct radiative transfer equation solver for path loss calculation in underwater communication systems. J. Opt. Commun. Networks. Vol. 5. No. I. 2013, pP. I-I2.

17. Gabriel C., Khalighi M.-A., Bourennane S. (20I5). Monte-Carlo-based channel characterization for underwater optical optical wireless channels. IEEE Wireless Commun. Lett. Vol. 4. No. 5, pp. 56I-564.

18. Mazin Ali A. Ali (2015). Comparison of Modulation Techniques for Underwater Optical Wireless Communication Employing APD Receivers. Research Journal of Applied Sciences, Engineering and Technology, pp. 56I-564.

\section{Информация об авторах:}

Петрухин Геннадий Дмитриевич, д.т.н., ведущий научный сотрудник Московского технического университета связи и информатики, Москва, Россия Мирошникова Наталия Евгеньевна, к.т.н., Научный сотрудник Московского технического университета связи и информатики, Москва, Россия Щербаков Алексей Валерьевич, Младиий научный сотрудник Московского технического университета связи и информатики, Москва, Россия Титовеи, Павел Александрович, ведущий инженер Московского технического университета связи и информатики, Москва, Россия 